\title{
KAJIAN SOSIAL EKONOMI DALAM UPAYA PENINGKATAN KESEJAHTERAAN PETANI BUNGA PADA GAPOKTAN SEKAR MULYA DAN GELORA BUNGA DESA SIDOMULYO, KEC. BATU, KOTA BATU
}

\author{
Yuni Setyawati ${ }^{1}$, Citra Setyowinahyu K.B. ${ }^{2}$ \\ 12 Universitas Tribhuwana Tunggadewi \\ warteragustim@gmail.com
}

\begin{abstract}
Ornamental plants have an agronomic value and a much higher economic value compared to the development of non-ornamental plants. Prices that are quite high can improve the economic level of rural communities. The purpose of this study is to examine the socio-economic factors that play a role in improving the welfare of business of Flower farmers, especially Gapar Sekar Mulya and Gelora Bunga in Sidomulyo Village, Kec. Batu Kota Batu. The method of data collection in this study is to observe directly to the research area and interview the resource persons consisting of flower farmers, especially those who are members of the Sekar Mulya Gapokjan and Flower surge. The results showed that the rate of income of these flower farmers averaged are more than 1 million rupiah per month. With the income earned, they are convinced that the entrepreneurial opportunity for ornamental plants is enough to promise a better future, and motivate them to be more active in ornamental plant business in order to obtain a better income level.
\end{abstract}

Keywords: Economy, Flower farmer, Social, Welfare

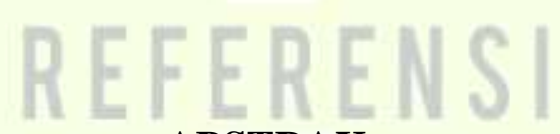

\section{ABSTRAK}

Tanaman hias memiliki nilai agronomis dan nilai ekonomis yang jauh lebih tinggi dibandingkan dengan pengembangan tanaman bukan tanaman hias. Harga yang cukup tinggi dapat meningkatkan taraf perekonomian masyarakat pedesaan. Tujuan penelitian ini untuk menelaah faktor-faktor sosial ekonomi yang berperan dalam peningkatan kesejahteraan usaha petani Bunga khususnya Gapoktan Sekar Mulya Dan Gelora Bunga di Desa Sidomulyo Kec. Batu Kota Batu. Metode pengumpulan data dalam penelitian ini adalah dengan melakukan obeservasi langsung ke daerah penelitian dan wawancara terhadap narasumber yang terdiri atas petani bunga terutama yang tergabung dalam gapokjan Sekar Mulya dan gelora Bunga. Hasil penelitian menunjukkan tingkat pendapatan para petani bunga ini rata-rata perbulan $>1$ juta. Dengan pendapatan yang diperoleh tersebut, mereka yakin bahwa peluang wirausaha tanaman hias ini cukup menjanjikan masa depan yang lebih baik, serta memotivasi mereka untuk lebih giat berwirausaha tanaman hias guna memperoleh tingkat pendapatan yang lebih baik lagi.

Kata kunci: Ekonomi, Kesejahteraan, Petani bunga, Sosial 
ISSN: 2089-0532, e-ISSN: 2548-6152

\section{PENDAHULUAN}

Indonesia merupakan negara agraris yang gemah ripah loh jinawi, dimana masyarakat khususnya pedesaan pada umumnya bercorak pertanian sebagai

basis ekonomi utamanya. Potensi yang tidak dimiliki oleh negara-negara lain. Dengan sentuhan teknologi dan peluang pasar yang sangat luas baik di dalam negeri maupun di manca negara, sektor pertanian berpotensi untuk diupayakan, dan memiliki prospektif sebagai pilihan wirausaha. Permintaan pasar yang semakin selektif dan semakin beragam, merupakan peluang besar yang semakin mengokohkan betapa besar peluang bisnis di bidang pertanian. Belum lagi jika budidaya pertanian diintegrasikan dengan peternakan sebagai pendukung kesuburan tanah alami.

Salah satu usaha bidang pertanian yang memiliki peluang cukup baik saat ini adalah usaha tanaman hias. Adapun manfaat Pengembangan tanaman hias untuk kehidupan manusia dapat digolongkan kedalam segi ekonomis, artistik dan sosial budaya. Pengembangan tanaman hias bermanfaat lebih luas dan bernilai ekonomis lebih besar dari pengembangan tanaman yang tidak termasuk dalam tanaman hias. Pengembangan tanaman hias dapat meningkatkan nilai ekonomis dari tanaman itu sendiri. Tanaman hias memiliki nilai agronomis dan nilai ekonomis yang jauh lebih tinggi dibandingkan dengan pengembangan tanaman bukan tanaman hias. Harga yang cukup tinggi dapat meningkatkan taraf perekonomian masyarakat pedesaan. Diharapkan dengan adanya peningkatan harga tanaman hias dan adanya peningkatan nilai ekonomis dari tanaman tersebut, maka akan meningkatkan taraf hidup dan sosial ekonomi masyarakat pedesaan.

Berdasar uraian diatas, dapat ditarik suatu perumusan masalah yakni faktor apa saja dalam sosial ekonomi yang berperan didalam upaya peningkatan kesejahteraan para petani terkait dalam usahanya di bidang tanaman hias. Tujuan penelitian ini untuk menelaah faktor-faktor sosial ekonomi yang berperan dalam peningkatan kesejahteraan usaha petani Bunga khususnya Gapoktan Sekar Mulya Dan Gelora Bunga di Desa Sidomulyo Kec. Batu Kota Batu.

\section{TINJAUAN PUSTAKA}

\section{Pengertian Sosial Ekonomi}

Situasi sosial setiap orang mempunyai perbedaan dan segi tingkatannya, ada yang keadaan sosial ekonominya tinggi, sedang, dan rendah. Sosial adalah cara tentang bagaimana para individu saling berhubungan . Yang dimaksud dengan Sosial adalah sesuatu yang dipahami sebagai suatu perbedaan namun tetap merupakan sebagai satu kesatuansegala sesuatu mengenai masyarakat dan kemasyarakatan.

Sedangkan istilah ekonomi itu sendiri berasal dari Bahasa Yunani yaitu dari kata oikonomia, kata oikos dan nomos, oikos berarti rumah tangga dan nomos berarti tata laksana atau pengaturan. Jadi ekonomi adalah adanya hubungan manusia dalam usahanya dengan produksi, distribusi, dan konsumsi terhadap barang dan jasa untuk memenuhikebutuhannya

\section{Ukuran Sosial Ekonomi}

Pembuatan skala ukuran bertujuan untuk mengetahui sisi 
ISSN: 2089-0532, e-ISSN: 2548-6152

menyeluruh dari seseorang yang bersedia dengan apa yang mereka sebut status sosial ekonomi, yang selalu artikan secara agak luas. Para ahli berupaya untuk membuat tingkat pencapaian dalam menentukan ukuran status sosial.

Warner menyusun empat komponen status sosial ekonomi seseorang, yaitu pekerjaan, asal pendapatan, tipe rumah dan lingkungan tempat tinggal. Sedangkan Hollinghead menyusun ukuran atas tiga komponen yaitu: lingkungan tempat tinggal, gengsi, pekerjaan dan pendidikan (Indrawati, 2009). Dalam hal ini penulis hanya membatasi empat komponen yaitu: pendapatan, kawasan tempat tinggal (lingkungan keluarga dan lingkungan).

\section{Minat Pemuda dalam mengembangkan tanaman hias}

\section{Definisi Pemuda}

Definisi PBB tentang
"pemuda" biasanya mencakupi
mereka yang berusia 15-24 tahun sehingga adanya perbedaan pendapat dengan peraturan perundang-undangan Indonesia dengan yang berstatus "anak" yang meliputi usia 0-17 tahun), peraturan perundangundangan Indonesia (seperti halnya di beberapa negara lain Asia, Afrika dan Amerika Latin) memperpanjang batas formal "pemuda" hingga usia yang tidak wajar.Undang-undang baru tentang status kepemudaan mendefinisikan pemuda sebagai "warga negara Indonesia yang memasuki periode penting pertumbuhan dan perkembangan yang berusia 16-30 tahun" (UU No. 40 Tahun 2009, Pasal 1.1). Alasan-alasan penguluran batas status "pemuda" hingga 30 tahun tidak adanya penjelasan yang jelas dalam UndangUndang atau "naskah akademik" . Sejalan dengan banyak pemerintah negara sedang berkembang lain yang menetapkan batas akhir pemuda hingga 35 bahkan sampai 40 tahun (Menpora, 2008 dalam Naafs dan White, 2012). Menurut Undang-Undang Republik Indonesia yang telah disahkan Nomor 40 Tahun 2009 tentang kepemudaan batasan usia pemuda dimulai dari umur 16-30 tahun yang membagi siklus kehidupan manusia dalam empat tahapan yaitu kanak-kanak 0-8 tahun, tahap remaja $9-16$ tahun, tahap dewasa 17-25 tahun, dan tahap orang tua 26 sampai seterusnya.

$$
\text { Menurut Syaiful Bahri }
$$

Djamarah (2008:132) "minat adalah kecenderungan yang menetap untuk memperhatikan dan mengenang beberapa aktivitas. Seseorang yang berminat terhadap aktivitas akan memperhatikan aktivitas itu secara konsisten dengan rasa senang."

Menurut kamus lengkap psikologi, minat (interest) adalah (1) satu sikap yang berlangsung terus menerus yang memolakan perhatian seseorang, sehingga membuat dirinya jadi selektif terhadap objek minatnya,

(2) perasaan yang menyatakan bahwa satu aktivitas, pekerjaan, atau objek itu berharga atau berarti bagi individu, (3) satu keadaan motivasi, atau satu set motivasi, yang menuntun tingkah laku menuju satu arah (sasaran) tertentu (dalam Chaplin, 2008:255).

$$
\text { Banyak ahli yang }
$$
mengemukakan mengenai jeni-jenis minat, salah satudiantaranya Carl safran dalam Sukardi (2003) mengklasifikasikan minat menjadi empat jenis yaitu : 
1. Minat yang diekspresikan melalui tulisan maupun ucapan yang menunjukkan apakah seseorang itu menyukai dan tidak menyukai suatu pekerjaan atau suatu benda yang nyata

2. Minat yang disimpulkan dari kegiatan yang diikuti individu pada suatu kegiatan tertentu.

3. Minat yang disimpulkan dari tes pengetahuan atau bakat/keterampilan yang dimiliki dalam suatu kegiatan.

4. Minat yang diungkapkan melalui penilaian minat atau daftar aktivitas yang sering dikerjakan/lakukan

\section{Indikator Minat}

Pada dasarnya minat menurutKarina (2009) dibagi menjadi empat unsur pokok yang sangat penting untuk meraih keberhasilan, yaitu:

1. Rasa Suka
Adanya perasaan Suka terhadap sesuatu akan menimbulkan minat, yang diperkuat dengan sikap yang positif. Perasaan senang seseorang biasa dilakukan dengan beberapa hal misal: semangat dalam melakasanakan aktivitas di bidang peternakan.

\section{Kepedulian}

Kata peduli memiliki makna yang beragam. Banyak literatur yang menggolongkannya berdasarkan orang yang peduli, orang yang dipedulikan dan sebagainya. Oleh karena itu kepedulian menyangkut tugas, peran, dan hubungan. Kata peduli juga berhubungan dengan pribadi, emosi dan kebutuhan (tronto dalam phillips, 2007).

Kepedulian merupakan cara memelihara hubungan dengan orang lain atau sesuatu yang di sukai yang bemula dari perasaan dan ditunjukkan dengan perbuatan seperti memperhatikan orang lain,menjaga sesuatu yang disuaki, belas kasih, dan menolong.Minat menentukan sukses dan gagalnya kegiatan seseorang. Kurangnya minat menyebabkan kurangnya kepedulian dalam bidang peternakan".

3. Pemahaman

Timbulnya minat dari diri seseorang dapat diawali dengan adanya pemahaman bahwa suatu objek itu mempunyai manfaat bagi dirinya.Pemahaman itu mutlak harus ada dan dengan pemahaman itu pula seseorang akan mengenai objek yang dirasa ada daya tarik bagianya. Bila seorang sudah memahami bahwa beternak dapat mendapatkan keuntungan dan membawa kemajuan pada dirinya, kemungkinan besar ia akan berminat untuk beternak.

4. Kesediaan

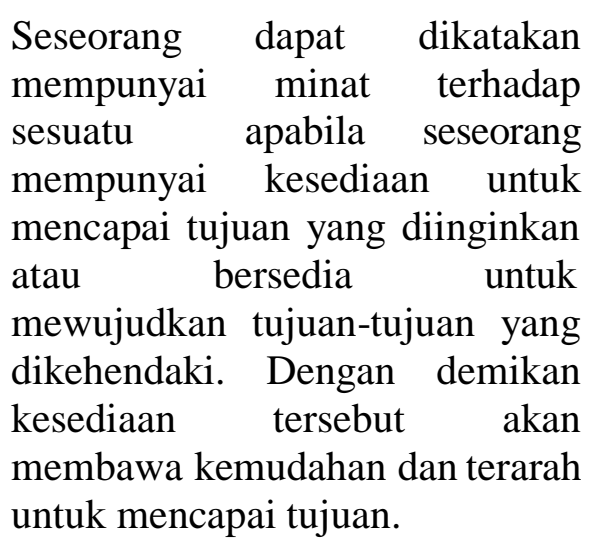


ISSN: 2089-0532, e-ISSN: 2548-6152

\section{Pengaruh Sosial Ekonomi terhadap Minat Pemuda dalam Beternak}

\section{Penghasilan}

Pengembangan para pengusaha peternakan diharapkan dapat memperlancar pertumbuhan ekonomi dengan meningkatkan penghasilan dan kemakmuran masyarakat, sehingga dapat memberikan peran nyata bagi pengembangan daerah. Hal ini dapat dikatakan bahwa sasaran utama usaha peternakan adalah untuk memperoleh laba (Pradasari, 2013)

Penghasilan atau laba merupakan tujuan dari usaha yang dilakukan. laba dapat diperoleh jika jumlah penerimaan lebih besar dari jumlah pengeluaran. Aspek pengahasilan merupakan salah satu hal yang digunakan untuk menilai tingkat kemampuan perusahaan atau pribadi dalam memperoleh penghasilan serta besarnya biaya yang dikeluarkan (Mulyajho, 2012)

\section{Kalangan kerabat}

Adapun minat beternak dipengaruhi oleh lingkungan keluarga seperti cara orang tua mendidik, suasana rumah, status sosial ekonomi dan jenis pekerjaan orang tua.

Kerabat adalah lingkungan dimana beberapa orang yang masih memiliki hubungan darah dan bersatu. Kerabat dapat didefinisikan sebagai sekumpulan orang yang tinggal dalam satu rumah yang masih mempunyai hubungan darah karena perkawinan, kelahiran, adopsi dan lain sebagainya. kerabat yang terdiri dari ayah, ibu dan anak- anak yang belum menikah disebut kerabat (Karina, 2009).

\section{Kalangan Warga Negara}

Kalangan warga negara merupakan tempat berbaurnya semua komponen, baik dari agama, etnis keturunan, status ekonomi maupun status sosial. Pengaruh yang ada pada kalangan warga negara dapat mempengaruhi seseorang terhadap dunia pendidikan. pengawasan dari warga negara juga akan membantu dalam pengembangan karakter dan ketertarikan dalam berwirausaha (Rawuh, 2010).

Dari kalangan Warga negara merupakan lingkungan di luar kerabat baik dikawasan tempat tinggal maupun di kawasan lain. Warga negara yang dapat mempengaruhi minat berwirausaha tentunya jika lingkungan tempat tinggal tersebut banyak orang yang berwirausaha, antara lain: tetangga, saudara, teman, kenalan dan orang lain. Misalnya, seseorang yang tinggal di daerah yang terdapat usaha peternakan atau sering bergaul dengan peternak yang berhasil akan menimbulkan minat berwirausaha di bidang peternakan (Hermina, 2011).

\section{Tingkatan Sosial}

Tingkatan sosial adalah suatu tempat sosial seseorang di masyarakat yang dapat diperoleh dengan sendirinya (otomatis) melalui usaha ataupun karena pemberian. Hubungan sosial akan mendorong seseorang untuk dapat mencapai tingkatan sosial yang lebih tinggi. kondisi sosial yang lebih tinggi akan berpengaruh pula pada tingkah laku dan rasa penghargaan yang tinggi dari masyarakat. Oleh karena itu, setiap orang akan berusaha untuk mencapai sosial yang lebih tinggi (Raharjo, 2009).

\section{METODE PENELITIAN}

Penelitian dilaksanakan di Desa Sidomulyo Kecamatan Batu Kota Batu. 
ISSN: 2089-0532, e-ISSN: 2548-6152

Desa tersebut dikenal sebagai Desa Sentra bunga, karena sebagian besar penduduknya adalah petani bunga, selain karena faktor Histori, serta faktor geografinya yang sangat sesuai untuk pertanian khususnya sektor tanaman Hias.

Metode pengumpulan data dalam penelitian ini adalah dengan melakukan obeservasi langsung ke daerah penelitian (Singarimbun dan effendi, 2002). Selain itu melakukan wawancara terhadap informan atau narasumber yang terdiri atas petani bunga terutama yang tergabung dalam gapokjan Sekar Mulya dan gelora Bunga. Adapun jumlah informan atau narasumber dapat ditentukan ketika informasi yang diperoleh peneliti dirasa sudah cukup. Berdasar penelitian dilapangan, jumlah narasumber sekitar 5 orang. Untuk mengetahui ke absahan data, maka perlu dilakuka triangulasi data yakni meng crosscek semua data yang diperoleh.

\section{HASIL DAN PEMBAHASAN}

Berdasarkan hasil wawancara dengan infoman atau narasumber yaki para petani tanaman hias. Bahwa faktor sosial ekonomi yang mampu mendorong meningkatnya kesejahteraan usaha mereka ditinjau dari tingkat pendapatan, lingkungan keluarga, lingkungan masyarakat serta status sosial.

Tingkat pendapatan para petani bunga ini rata-rata perbulan $>1$ juta. Dengan pendapatan yang diperoleh tersebut, mereka yakin bahwa peluang wirausaha tanaman hias ini cukup menjanjikan masa depan yang lebih baik, serta memotivasi mereka untuk lebih giat berwirausaha tanaman hias guna memperoleh tingkat pendapatan yang lebih baik lagi. Tingkat pendapatan yang mengalami peningkatan dapat dilihat dari pertambahan luas lahan petani, pertambahan variasi produk, serta jenis bunga yang semakin variatif. Perlu diketahui bahwa pendapatan merupakan hal yang pokok dalam kehidupan baik untuk keberlangsungan usahanya maupun untuk memenuhi segala kebutuhan rumah tangganya. Menurut Suhartini (2011:45) dalam Mulyadi (2017), Berwiraswasta dapat memberikan pendapatan yang dapat digunakan untuk memenuhi kebutuhan hidupnya.

Terkait dengan Lingkungan keluarga, hampir sebagian besar usaha tanaman hias ini merupakan usaha keluarga (orangtua) tentunya keluarga akan sangat mendukung serta memotivasi anggota keluarganya untuk menekuni wirausaha dibidang yang sama. lingkungan keluarga adalah media pertama dan utama yang berpengaruh terhadap perilaku dalam perkembangan anak. Lingkungan keluarga merupakan kelompok terkecil di masyarakat yang terdiri dari ayah, ibu, anak dan anggota keluarga lainnya. Lingkungan keluarga terutama orang tua berperan penting dalam perkembangan dan pertumbuhan anak. Orang tua juga berperan sebagai pengarah bagi masa depannya, artinya secara tidak langsung orang tua juga dapat mempengaruhi minat anaknya dalam memilih pekerjaan termasuk dalam hal menjadi wirausaha. Hal ini sejalan dengan apa yang disampaikan oleh Westy Soemanto (2008: 38) bahwa orang tua atau keluarga merupakan peletak dasar bagi persiapan anak-anak agar di masa yang akan datang dapat menjadi pekerja yang efektif.

Terkait Lingkungan Masyarakat, Hampir sebagian besar lingkungan masyarakat sekitar desa Sidomulyo mempunyai usaha tanaman hias baik yang berlokasi di lahan pertanian maupun halaman rumah penduduk. Bahkan disepanjang jalan menuju tempat wisata, banyak berdiri stan-stan 
ISSN: 2089-0532, e-ISSN: 2548-6152

usaha tanaman hias. Hal inilah mengapa desa sidomulyo dinamakan sebagaiDesa Wisata Bunga. Adanya kegiatankegiatan dalam masyarakat yang terkait dengan wirausaha tanaman hias, Mass media baik internet, televisi maupun majalah atau koran, dorongan dari Teman bergaul serta Bentuk kehidupan masyarakat Sidomulyo yang sebagian besar berwirausaha tanaman hias, tentunya akan mampu mendorong kemajuan dari usaha, yang pada akhirnya berimbas pada kesejahteraan hidup petani bunga.

Terkait dengan status sosial, sesorang yang memiliki pekerjaan dengan penghasilan yang cukup yaitu dengan berwirausaha tanaman Hias, mereka merasa lebih dihargai atau disegani oleh masyarakat. status sosial yang lebih tinggi akan berpengaruh pula pada sikap dan rasa penghargaan yang tinggi dari masyarakat. Oleh karena itu, setiap orang akan berusaha untuk mencapai status sosial yang lebih tinggi. Begitu juga pernyataan Ahira (2012), bahwa status sosial terjadi karena adanya sesuatu yang dihargai banyak orang cenderung melakukan kegiatan usaha dengan dasar agar posisi mereka dimata masyarakat akan lebih tinggi dibandingkan dengan hanya sekedar menjadi buruh.

\section{KESIMPULAN}

Secara keseluruhan gambaran tentang faktor sosial ekonomi yang meliputi pendapatan, lingkungan keluarga, lingkungan masyarakat serta status sosial di Desa Sidomulyo cukup mendorong kesejahteraan masyarakat khususnya petani bunga. Tingkat pendapatan yang baik, lingkungan yang kondusif baik keluarga dan masyarakat serta status sosial berdampak cukup baik terhadap perkembangan usaha .
Terima kasih disampaikan kepada Dikti yang telah mendanai penelitian ini. Selanjutnya ucapan terima kasihdisampaikan kepada masyarakat dan pemerintahan Desa Sidomulyo yang telah mendukung semua kegiatan ini

\section{DAFTAR PUSTAKA}

Ahira, A. 2012. Status Social Ekonomi Masyarakat. http//www-.anneahiara.-

/com.status.sosial.ekonomi.masy arakat.html. Diakses \{Tanggal 10 April 2013\}.

Arvianti E.Y, Asnah, Anung prasetyo. 2015. Minat pemuda tani terhadap transformasi Sektor pertanian di kabupaten ponorogo. Buana sains vol 15 no 2: 181-188.Ps. Agribisnis, fak. Pertanian. Universitas tribhuwana tunggadewi

Buchari Alma. (2013). Kewirausahaan. Bandung: Alfabeta.

Conny Semiawan. (2010). Pendidikan Keluarga Dalam Era Global. Jakarta: PT. Preenhalindo.

Chomzana Kinta Marini. (2014). Pengaruh Self-Efficacy, Lingkungan Keluarga,dan Lingkungan Sekolah terhadap Minat Berwirausaha Siswa SMK Jasa Boga. Jurnal Pendidikan Vokasi, Vol 4, Nomor 2, Juni 2014. Hlm. 195-207.

Dalimunthe, R. 2002. Pengaruh Karakteristik Individu, Kewirausahaan, Gaya Kepemimpinan terhadap Kemampuan Usaha serta Keberhasilan Usaha Industri Kecil Tenun dan Bordir di Sumatra Utara, Sumatra Barat dan Riau. Disertasi, Universitas Airlangga.

\section{Ucapan Terima Kasih}


ISSN: 2089-0532, e-ISSN: 2548-6152

Davidsonn, P., \& Honig, B. 2003. The role of social and human capital among nascent entrepreneurs. Journal of Business Venturing 18:301-331.

Fitra Fajar Abdillah, Sampeadi Wiji Utami. (2013). Faktor-Faktor yang Mempengaruhi Minat Berwirausaha Siswa Jurusan Agribisnis pada SMK Negeri 1 Kalibaru. Artikel Ilmiah Mahasiswa 2013. Hlm. 1-6.

Hazirah Amalia Ayuningtias dan Sanny Ekawati. (2015). Faktor-Faktor yang Mempengaruhi Minat Berwirausaha Pada Mahasiswa Fakultas Ekonomi Universitas Tarumanegara. Jurnal Ekonomi, Volume 10, Nomor 1, Maret2015. HIm 49-71.

Kementrian Riset dan Teknologi. 2012. Startup entrepreneurship (Online). Diakses 05 Desember 2015. http://www.ristek.go.id

Kumbhar, V. 2013. Some critical issues of women entrepreneurship in Rural India. European Academic Research 1(1):5.

Mulyadi, H. 2017. Faktor yang berpengaruh terhadap minat berwirausaha mahasiswa manajemen bisnis syariah fakultas ekonomi dan bisnis islam iain surakarta. Skripsi. Institut agama islam negeri surakarta

Munizu, M. 2010. Pengaruh faktorfaktor eksternal dan internal terhadap kinerja usaha mikro dan kecil (UMK) di Sulawesi Selatan. Jurnal Manajemen dan Kewirausahaan 12(1): 33-41.

Raharjo, P. 2009. Sosiologi 2: untuk SMA/MA Kelas XI. Jakarta: Pusat Perbukuan Pendidikan Nasional.

Rante, Y. 2010. Pengaruh Budaya Etnis dan Perilaku Kewirausahaan Terhadap
Kinerja Usaha Mikro Kecil Agribisnis di Provinsi Papua. Jurnal Manajemen dan Kewirausahaan12(2) : 133-141.

Sanputi, S. 2010. Analisis faktor-faktor yang memotivasi wanita berwirausaha (studi pada pengusaha salon kecantikan pada Kecamatan Medan Tembung). Jurnal Keuangan dan Bisnis 2(3):258.

Sasongko, A. 2015. Jumlah pengusaha Indonesia hanya 1,65 persen (Online). Diakses Agustus 2015.

http://nasional.republika.co.id/beri ta/nasional/umum/15/08/13/nl3

i58-jumlahpengusahaindonesiahanya-165-persen

Subyantoro, A. 2009. Karakteristik Individu, Karakteristik Pekerjaan, Karakteristik Organisasi dan Kepuasan Kerja Pengurus yang Dimediasi oleh Motivasi Kerja (Studi pada Pengurus KUD di Kabupaten Sleman). Jurnal Manajemen dan Kewirausahaan11(1) : 11-19.

Suhartini Yati, (2011), Analisis FaktorFaktor Yang Mempengaruhi Mahasiswa Dalam Berwiraswasta. Syafiudin,A. 2016. Pengaruh kepribadian, lingkungan keluarga dan Pendidikan kewirausahaan terhadap minat Berwirausaha mahasiswa program studi akuntansi Universitas negeri yogyakarta. Skripsi.

Syarif, D. 2015. Teori-Teori Manajemen Dan Organisasi (Online). Diakses Desember 2015. http://theorymanajemendanorgani sasi.blogspot.co.id/2015/12/karakt eristik-individu.html

Westy Soemanto. (2008). Pendidikan Wirausaha. Jakarta: PT. Bumi Aksara. 